\title{
Catalytic pyrolysis of linear low-density polyethylene using recycled coal ash: Kinetic study and environmental evaluation
}

\author{
Jianchen Lai ${ }^{*, *}$, Yang Meng ${ }^{* *, *}$, Yuxin Yan ${ }^{* * *}$, Edward Lester ${ }^{* * * *}$, Tao Wu ${ }^{* * * *}$, and Cheng Heng Pang ${ }^{* *, * * * * *, \dagger}$ \\ *Department of Chemical and Environmental Engineering, University of Nottingham Ningbo China, \\ Ningbo 315100, P. R. China \\ **New Materials Institute, University of Nottingham Ningbo China, Ningbo 315042, P. R. China \\ ***Key Laboratory for Carbonaceous Wastes Processing and Process Intensification Research of Zhejiang Province, \\ University of Nottingham Ningbo China, Ningbo 315100, P. R. China \\ $* * * *$ Department of Chemical and Environmental Engineering, University of Nottingham, Nottingham NG7 2RD, UK \\ *****Municipal Key Laboratory of Clean Energy Conversion Technologies, University of Nottingham Ningbo China, \\ Ningbo 315100, China \\ (Received 28 February 2021 • Revised 16 June 2021 • Accepted 19 June 2021)
}

\begin{abstract}
Catalytic pyrolysis offers a sustainable route to convert plastic wastes into fuel. We investigated the catalytic performance of coal ash (fly and bottom ash) at blending ratio of $5 \mathrm{wt} \%$, and $15 \mathrm{wt} \%$ during pyrolysis of linear lowdensity polyethylene (LLDPE). The influence on activation energy and oil was characterized via thermogravimetric analyzer (TGA) and gas chromatography-mass spectrometry (GC-MS). Results have shown that 15 wt\% bottom ash exhibited higher catalytic activity. The activation energy estimated by Coats-Redfern method decreased from 458.7 $\mathrm{kJ} \cdot \mathrm{mol}^{-1}$ to $437.8 \mathrm{~kJ} \cdot \mathrm{mol}^{-1}$, while the alicyclic hydrocarbon yield increased from $5.97 \%$ to $32.09 \%$. This implies that $\mathrm{CaO}$, which is abundant in bottom ash, could promote the conversion of LLDPE. Furthermore, a cradle-to-factory gate life cycle assessment was performed to investigate three scenarios (non-catalytic pyrolysis, $15 \mathrm{wt} \%$ fly ash, and $15 \mathrm{wt} \%$ bottom ash) of LLDPE conversion strategies via a normalization and weighting approach. It was found that LLDPE pyrolysis with $15 \mathrm{wt} \%$ bottom ash also showed the lowest normalized score of 2.83 , implying the lowest environmental impact. This work has demonstrated that the recycling of coal ash, particularly bottom ash, as catalysts for LLDPE pyrolysis is effective.
\end{abstract}

Keywords: Waste Management, Catalyst, Catalytic Pyrolysis, Coats-Redfern Method, Normalization and Weighted Scores

\section{INTRODUCTION}

Linear low-density polyethylene (LLDPE) is of the main plastics used worldwide [1]. The current demand for polyethylene polymers in personal protective equipment such as masks has surged owing to the COVID-19 pandemic. However, such materials generate large amounts of plastic waste with a low recovery rate, which leads to increased pollution [2,3]. Pyrolysis, particularly catalytic pyrolysis, is a key waste-to-energy technology for converting waste materials into high energy density products. The catalytic pyrolysis of plastics is usually conducted in the presence of catalysts by rapid heating to a high temperature $[4,5]$. However, the lack of inexpensive and effective catalysts limits the development of catalytic pyrolysis for plastic wastes [6]. Metal oxide, particularly alkali and alkali earth metals (AAEMs) oxides, has been extensively investigated in the past two decades and is becoming increasingly popular as industrial catalyst owing to its high catalytic performance and low costs [7]. Previous studies have shown that $\mathrm{Fe}_{2} \mathrm{O}_{3}$ and $\mathrm{CaO}$ can pro-

\footnotetext{
${ }^{\dagger}$ To whom correspondence should be addressed.

E-mail: ChengHeng.Pang@nottingham.edu.cn

${ }^{\ddagger}$ Both authors have contributed equally to this work.

Copyright by The Korean Institute of Chemical Engineers.
}

mote the cracking of long-chain hydrocarbons and lower the bond energy of oxygen-containing functional groups to increase gas yield [8]. Similarly, Franklin and co-workers [9] investigated the pyrolysis behavior of bituminous coal and found that the addition of $\mathrm{CaO}$ could increase the yield of $\mathrm{CO}$ via the catalytic decomposition of phenolic groups. In another study, the addition of $\mathrm{Fe}_{2} \mathrm{O}_{3}$ in sewage sludge pyrolysis not only promoted the gas yield and biooil but also facilitated the $\mathrm{CO}$ and $\mathrm{H}_{2}$ formation [10]. For these cases, it is possible to summarize that free radical and $\beta$ carbanion mechanisms induced by base metal oxide facilitate the conversion of polymers through the formation of unstable carbanion structure $[11,12]$.

Coal ash is an inexpensive industrial waste product, with annual output estimated to be $500 \mathrm{Mt}$ in China [13]. Improper handling of coal ash may cause environmental pollution, such as mercury leakage [14]. However, management of mercury $[15,16]$ in coal ash requires a complex operation causing considerable additional investment. Coal ash contains abundant mineral components such as $\mathrm{SiO}_{2}, \mathrm{Al}_{2} \mathrm{O}_{3}, \mathrm{CaO}, \mathrm{Fe}_{2} \mathrm{O}_{3}$, and $\mathrm{MgO}$ [17]; thus, many researchers have used this material as a catalyst in pyrolysis [18]. For example, Gao et al. [19] found that the ratio of coal fly ash within wheat straw expanded from $1 \mathrm{wt} \%$ to $10 \mathrm{wt} \%$ and thus expanded the conversion of the biomass. In addition, coal fly ash can be used as an inex- 
pensive catalyst in biomass pyrolysis to yield heterogeneous sorbents with upgraded adsorption capacity for organic pollution. Young et al. [20] showed that coal fly ash can be made into solid catalysts through a simple preparation method for recycling biodiesel with a high conversion rate. This method includes mechanical treatment, acid activation, and basic activation. Benedetti et al. [21] determined that fly ash after mechanical and basic activation is a better catalyst than that after mechanical and acid activation, or raw fly ash. This catalyst significantly increased the content of light oil in the product as well as the content of styrene in the oil. The study by Parikh and Rotliwala [22] showed that a synergy of reactive species exists in reactions of high-density polyethylene in pyrolysis using coal fly ash as catalyst. Co-processing increased the aromatics and oxygen-containing compounds in the liquid product. However, previous studies were largely focused on fly ash or fly ash-derived catalysts [20-23], and limited studies have been carried out to investigate the catalytic effects of different ash deposits (collected from various parts of a coal-fired power station) on LLDPE pyrolysis. This study explores the catalytic influence of different mineral assemblage associated with different ash deposits owing to different formation processes and conditions [24-26]. Therefore, with a comprehensive understanding of ash chemistry, it is possible to locate the 'right' ash deposit to effectively promote plastic waste conversion.

This study was designed to explore the pyrolytic behavior of coal fly ash and coal bottom ash in LLDPE pyrolysis. LLDPE and coal ash including both fly ash and bottom ash were pyrolyzed in a thermogravimetric analyzer (TGA) under a nitrogen atmosphere owing to the high-accuracy assessment in the thermal behavior of organics in TGA and the fact that TGA was wildly used in plastic pyrolysis [27-30]. The activation energy was estimated by the CoatsRedfern method. The component of coal ash was characterized by $\mathrm{X}$-ray fluorescence (XRF) to investigate the active components in the coal ash. The liquid product composition was tested by a gas chromatography-mass spectrometry (GC/MS) to evaluate the effect of catalytic pyrolysis. In addition, this study provides a detailed comparison between non-catalytic pyrolysis and catalytic pyrolysis on the potential environmental impact via life cycle assessment (LCA). More specifically, this work explains the catalytic effect of industrial waste based on experimental data. The results, combined with LCA, imply the impact of various choices on the environment, which could play an important role for policymakers in formulating environmental regulations.

\section{EXPERIMENT}

\section{Sample Preparation}

The LLDPE sample was purchased from Guangdong Shunjie Plastic Technology Co. Ltd, while the ash samples were supplied from Ninghai Coal Power Plant China. The LLDPE sample was received as small particles (less than $250 \mu \mathrm{m}$ ). All ash samples were then ground into tiny particles below $150 \mu \mathrm{m}$.

\section{Sample Characterization}

\section{2-1. Laboratory Scale Pyrolysis}

LLDPE and LLDPE blending with coal fly ash or coal bottom ash samples was pyrolyzed in a tube furnace to study the pyrolysis behavior. The pyrolysis temperature was set at $550{ }^{\circ} \mathrm{C}$, with a heating rate of $10^{\circ} \mathrm{C} / \mathrm{min}$ under constant nitrogen flowrate of $120 \mathrm{ml} /$ min. A condenser connected to the system outlet was used to collect oil for yield calculation [31]. The weight of solid residue and synoil was calculated by electronic balance. The gasses were calculated from the initial mass of LLDPE minus the weight of solid residue and synoil.

\section{2-2. Pyrolytic Product Characterization}

The oil composition was characterized using gas chromatography-mass spectrometry (GC-MS, Agilent 7890-5975C, USA). The oven was on standby at $60^{\circ} \mathrm{C}$, with helium as carrier gas, before being heated to $280^{\circ} \mathrm{C}$ at a heating rate of $10^{\circ} \mathrm{C} / \mathrm{min}$ and with a split ratio was set to $50: 1$ [32].

2-3. Proximate and Mineral Analysis

The proximate composition of coal ash and LLDPE was determined by a TGA compiled with a differential scanning calorimeter (TGA-DSC, NETZSCH STA449F3, Germany). Briefly, $10 \mathrm{mg}$ of LLDPE, fly ash, and bottom ash was loaded into the TGA crucible, and the program was set from room temperature to $110^{\circ} \mathrm{C}$ in a nitrogen atmosphere. These conditions were held for $6 \mathrm{~min}$ to ensure moisture exclusion. The samples were then heated to $900{ }^{\circ} \mathrm{C}$ at a rate of $15^{\circ} \mathrm{C} / \mathrm{min}$; then, the gas atmosphere was changed to air, and the conditions were held for $5 \mathrm{~min}$ to ensure the that fixed carbon was completely burned off. Ultimate analysis was performed to determine the elements present in the LLDPE using an Elemental Analyzer (Elementar Vario EL, Germany), following the same analytical procedure published elsewhere [33]. The mineral composition of coal ash was determined using an X-ray Fluorescence (XRF) analyzer (Bruker S4-Explorer, USA). The differences in chemical composition could lead to varied catalytic effects of coal ash. In this study, two empirical indices were introduced to describe the characteristics of fly and bottom ash [34-36], as shown below:

$$
\begin{aligned}
& \text { Base to acid ratio: } \\
& \mathrm{R}_{B / A}=\frac{\mathrm{Na}_{2} \mathrm{O}+\mathrm{MgO}+\mathrm{K}_{2} \mathrm{O}+\mathrm{CaO}+\mathrm{Fe}_{2} \mathrm{O}_{3}}{\mathrm{Al}_{2} \mathrm{O}_{3}+\mathrm{SiO}_{2}}
\end{aligned}
$$

Iron to calcium ratio:

$$
\mathrm{R}_{\mathrm{Fe} / \mathrm{Ca}}=\frac{2 \times \mathrm{Fe}_{2} \mathrm{O}_{3}}{\mathrm{CaO}}
$$

where $\mathrm{Na}_{2} \mathrm{O}, \mathrm{MgO}, \mathrm{K}_{2} \mathrm{O}, \mathrm{CaO}, \mathrm{Fe}_{2} \mathrm{O}_{3}, \mathrm{Al}_{2} \mathrm{O}_{3}, \mathrm{SiO}_{2}$, is the weight percentage of each mineral oxide in ash sample. Both fly ash and bottom ash samples were evaluated using $\mathrm{R}_{B / A}$ and $\mathrm{R}_{\mathrm{Fe} / \mathrm{Ca}}$ indices, which could indicate the catalytic activity of ash samples during plastic pyrolysis [35-37].

\section{Kinetic Studies}

Compared with model-free methods, model-fitting methods obtain more kinetic parameters [38]. Thus, the Coats-Redfern integral method $[33,39]$ was adopted to calculate the kinetic parameters of LLDPE pyrolysis. The first-order reaction mechanism was chosen because it is the primary mechanism [40]. Most kinetic models use the Arrhenius equation and the conversion rate equation, as shown in Eqs. (1) and (2), respectively.

$$
\mathrm{K}(\mathrm{T})=\mathrm{A} \times \exp \left(-\frac{\mathrm{E}}{\mathrm{RT}}\right)
$$




$$
\frac{\mathrm{d} \alpha}{\mathrm{dt}}=\mathrm{A} \times \exp \left(-\frac{\mathrm{E}}{\mathrm{RT}}\right)(1-\alpha)^{n}
$$

where $\mathrm{T}$ is the absolute temperature $(\mathrm{K}) ; \mathrm{R}$ is the universal gas constant $\left(0.008314 \mathrm{~kJ} \cdot \mathrm{mol}^{-1} \cdot \mathrm{K}^{-1}\right) ; \mathrm{n}$ is the order of reaction; $\mathrm{t}$ is the time(s); $\mathrm{A}$ is the frequency or pre-exponential factor, and $\mathrm{E}$ is the activation energy of the reaction $\left(\mathrm{kJ} \cdot \mathrm{mol}^{-1}\right)$. Conversion degree $\alpha$ is defined as the mass change of the biomass sample at time $t$ which represents the relationship between initial mass $\mathrm{m}_{0}$, final mass $\mathrm{m}_{f}$ and current mass $\mathrm{m}_{t}$ of the system, as described in Eq. (3)

$$
\alpha=\frac{\mathrm{m}_{0}-\mathrm{m}_{t}}{\mathrm{~m}_{0}-\mathrm{m}_{f}}
$$

For the constant heating rate of $\beta$ where $\beta=\mathrm{dT} / \mathrm{dt}$, the following Eq. (4) can be obtained:

$$
\frac{\mathrm{d} \alpha}{\mathrm{dT}}=\frac{\mathrm{d} \alpha}{\mathrm{dt}} \times \frac{\mathrm{dt}}{\mathrm{dT}}=\frac{\mathrm{d} \alpha}{\mathrm{dt}} \times \frac{1}{\beta}
$$

Eq. (4) can be substituted into Eq. (2) to yield the following Eq. (5):

$$
\frac{\mathrm{d} \alpha}{\mathrm{dT}}=\frac{\mathrm{A}}{\beta} \times \exp \left(-\frac{\mathrm{E}}{\mathrm{RT}}\right)(1-\alpha)^{n}
$$

Integrating and expressing Eq. (5) in the logarithmic form will result in the following Eqs. (6) and (7):

$$
\begin{aligned}
& \ln \left[\frac{1-(1-\alpha)^{1-n}}{\mathrm{~T}^{2}(1-\mathrm{n})}\right]=\ln \left[\frac{\mathrm{AR}}{\beta \mathrm{E}}\left[1-\frac{2 \mathrm{RT}}{\mathrm{E}}\right]\right]-\frac{\mathrm{E}}{\mathrm{RT}}(\text { for } \mathrm{n} \neq 1) \\
& \ln \left[\frac{-\ln (1-\alpha)}{\mathrm{T}^{2}}\right]=\ln \left[\frac{\mathrm{AR}}{\beta \mathrm{E}}\left[1-\frac{2 \mathrm{RT}}{\mathrm{E}}\right]\right]-\frac{\mathrm{E}}{\mathrm{RT}}(\text { for } \mathrm{n}=1)
\end{aligned}
$$

For most systems, $\mathrm{RT} / \mathrm{E}<<1$ and $1-\frac{2 \mathrm{RT}}{\mathrm{E}} \approx 1$. Thus, Eqs. (6) and (7) can be further simplified as

$$
\begin{aligned}
& \ln \left[\frac{1-(1-\alpha)^{1-n}}{\mathrm{~T}^{2}(1-\mathrm{n})}\right]=\ln \left[\frac{\mathrm{AR}}{\beta \mathrm{E}}\right]-\frac{\mathrm{E}}{\mathrm{RT}}(\text { for } \mathrm{n} \neq 1) \\
& \ln \left[\frac{-\ln (1-\alpha)}{\mathrm{T}^{2}}\right]=\ln \left[\frac{\mathrm{AR}}{\beta \mathrm{E}}\left[1-\frac{2 \mathrm{RT}}{\mathrm{E}}\right]\right]-\frac{\mathrm{E}}{\mathrm{RT}}(\text { for } \mathrm{n}=1)
\end{aligned}
$$

Plotting $\ln \left[\frac{-\ln (1-\alpha)}{T^{2}}\right]$ against $1 / T$ gives a fitting line having a slope of $-\mathrm{E} / \mathrm{R}$ and an intercept of $\ln \mathrm{AR} / \beta \mathrm{E}$. Activation energy and preexponential factor $\mathrm{A}$ are derived from these values.
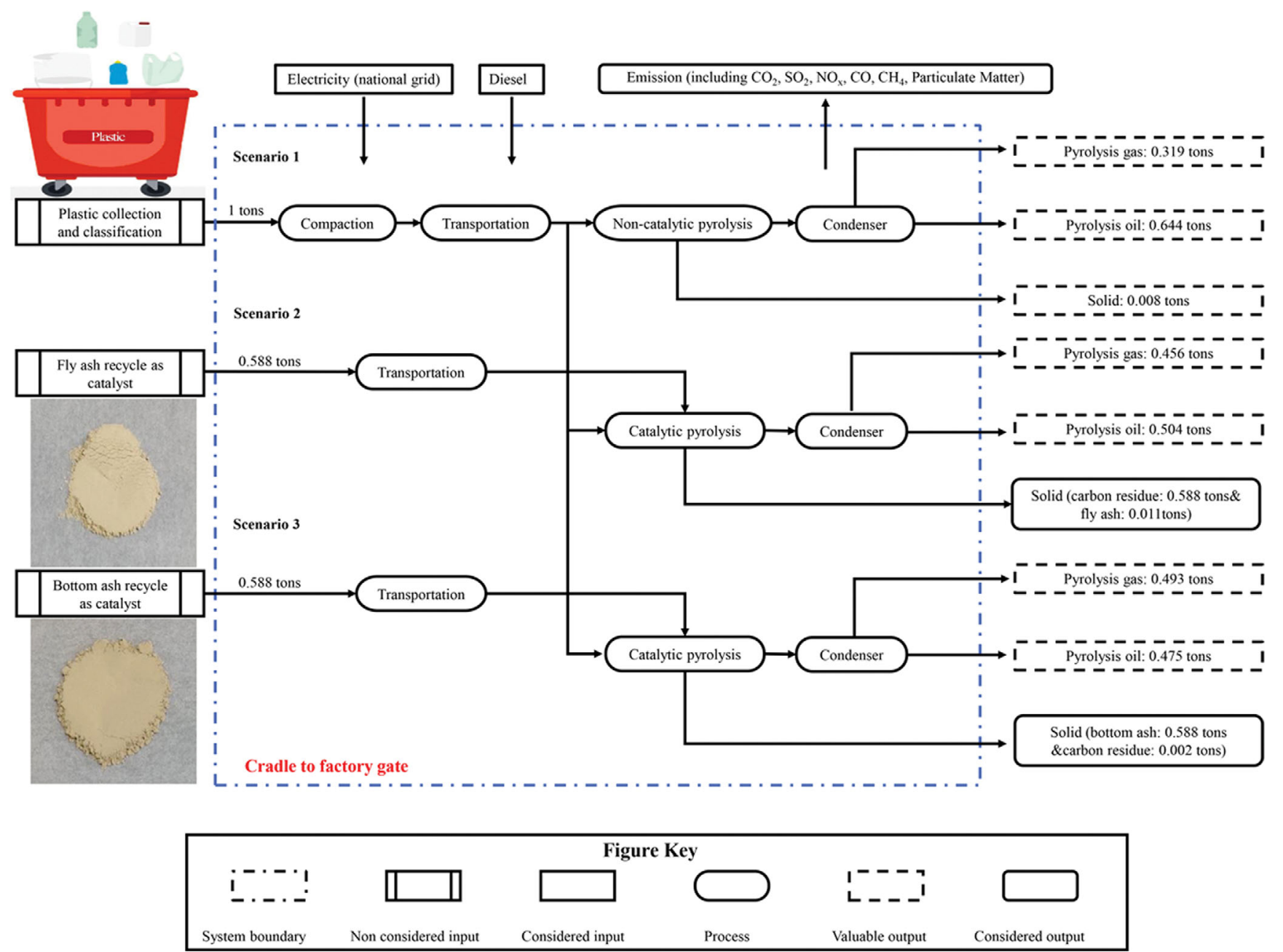

Fig. 1. Process of life cycle assessment. 
Table 1. Pyrolysis output with coal ash and non-catalyst

\begin{tabular}{lccc}
\hline \hline & $\begin{array}{c}\text { Non-catalytic } \\
\text { pyrolysis }\end{array}$ & $\begin{array}{c}\text { Catalytic pyrolysis } \\
(15 \text { wt\% fly ash })\end{array}$ & $\begin{array}{c}\text { Catalytic pyrolysis } \\
(15 \text { wt } \% \text { bottom ash })\end{array}$ \\
\hline Solid & 0.81 & 1.12 & 0.17 \\
Oil & 66.35 & 51.91 & 48.98 \\
Gas & 32.84 & 46.97 & 50.85 \\
\hline
\end{tabular}

Table $2.50 \%$ conversion rate time-consuming and electricity consumption reduction

\begin{tabular}{cccc}
\hline \hline & $\begin{array}{c}\text { Non-catalytic } \\
\text { pyrolysis }\end{array}$ & $\begin{array}{c}\text { Catalytic pyrolysis } \\
(15 \mathrm{wt} \% \text { fly ash })\end{array}$ & $\begin{array}{c}\text { Catalytic pyrolysis } \\
(15 \mathrm{wt} \% \text { bottom ash })\end{array}$ \\
\hline Time consumption & 3.93 & 3.78 & 3.65 \\
Variation amplitude & 0 & -3.82 & -7.12 \\
\hline
\end{tabular}

\section{LCA METHODOLOGY}

The objective of the work was to evaluate the life cycle environmental impact of LLDPE non-catalytic pyrolysis and catalytic pyrolysis [41-43]. The functional unit was the pyrolysis of one ton of LLDPE. Fig. 1 presents the system boundary for LLDPE pyrolysis including raw materials processing, transportation, and pyrolysis. The production processes were excluded from the analysis because the scope was cradle-to-factory gate. Three scenarios were tested, as described below.

- Scenario 1: LLDPE undergoes non-catalytic pyrolysis.

- Scenario 2: Coal fly ash is sent for catalytic pyrolysis with LLDPE at a blend ratio of $15 \mathrm{wt} \%$.

- Scenario 3: Coal bottom ash is sent for catalytic pyrolysis with LLDPE at a blend ratio of $15 \mathrm{wt} \%$.

In addition, several factors were considered in the LCA report, as given below.

- The geographical data of a pyrolysis/recycling plant in Ningbo Wangchun Industrial Park, the Ninghai Coal Power Plant in China, is considered as power station reference.

- The Chinese national grid supplies electrical energy.

- The transportation and electricity data are obtained from Chinese reference life cycle database [44].

- For transportation process, only the consumption in LLDPE, coal ash, and waste solid transportation are considered.

- LLDPE processing considers only the compaction process.

- The pyrolysis parameters are obtained by experiments.

- The ash catalyst can be reused three times [20]; the mass of ash used in each pyrolysis can be calculated as one-third, and the disposal of ash is not considered.

- Pollutant emissions are considered only from electricity production and diesel.

- Solid waste is considered only from LLDPE pyrolysis; waste treatment (landfilling) is included in the system boundaries.

\section{Pyrolysis System}

Coal ash can affect the product consumption and the reduction in energy consumption in LLDPE pyrolysis. The composition of the product is determined by pyrolysis laboratory-scale experiment, as shown in Table 1, and the reduction in energy consumption can be estimated according to the time needed for the reaction con- version rate to reach $50 \%$ in the TGA data, as shown in Table 2 .

\section{Avoided Products from Valuable Products}

Three types of valuable products are produced by LLDPE pyrolysis: syngas, synoil, and solid product. Fewer amounts of recycled material than fresh material are generally used because the recycling process causes changes in its physical and chemical properties. Thus, it is important to assume a substitution factor between recycled and raw materials. The valuable products of pyrolysis and their substitutes are discussed below.

Synoil can be substituted for diesel in diesel generators. The calculated cetane index (CCI) is a crucial parameter that must be carefully considered when using unconventional fuel inside a compression ignition engine. The CCI is calculated from the formula given below (ASTM D976).

$$
\mathrm{CCI}=454.74-1641.416 \mathrm{D}+774.74 \mathrm{D}^{2}-0.554 \mathrm{~B}+97.803(\log (\mathrm{B}))^{2}
$$

where, $\mathrm{D}$ is the fuel density at $15^{\circ} \mathrm{C}(\mathrm{g} / \mathrm{ml})$ and $\mathrm{B}$ is the mid-boiling temperature $\left({ }^{\circ} \mathrm{C}\right)$ corresponding to a $50 \%$ point in the distillation curve.

Gopinath et al. [45] measured the CCI of diesel and low-density polyethylene (LDPE). The CCI value of diesel was estimated to be 46, and the calculated CCI value of LDPE oil should be 49 . The LLDPE had the same chemical composition but showed some variation in the physical properties. Therefore, it is impractical to substitute $100 \%$ synoil for diesel fuel. Based on this explanation, a factor of 0.8 was determined for synoil to diesel.

Syngas can be substituted for natural gas. A higher heating value (HHV) is a vital parameter for its utilization as an alternative fuel. The HHV of natural gas is $52.2 \mathrm{MJ} / \mathrm{kg}$; that of syngas is $48.6 \mathrm{MJ} /$ $\mathrm{kg}$, as determined by López et al. [6] The result in industrial applications might be lower than the experimental data. Thus, a factor of 0.8 was determined for syngas to natural gas.

The solid product from LLDPE non-catalytic pyrolysis contains carbon black, which can be substituted for any commercial carbon black. However, the yield of carbon black from polymer pyrolysis with plasma treatment reached only $81 \%-82 \%$ [46]. For this reason, it was assumed that $1 \mathrm{~kg}$ of pyrolytic solid product can count as $0.5 \mathrm{~kg}$ of commercial carbon black.

\section{Life Cycle Inventory (LCI)}

The input-output data for the non-catalytic and catalytic pyroly- 
Table 3. Input-output data for non-catalytic pyrolysis of LLDPE [41,44,47]

\begin{tabular}{|c|c|c|c|c|c|}
\hline \multicolumn{6}{|c|}{1 ton of LLDPE sent to non-catalytic pyrolysis } \\
\hline \multicolumn{3}{|l|}{ Considered input } & \multicolumn{3}{|c|}{ Valuable output (all in kg) } \\
\hline Electricity & $214.30 \mathrm{MJ}$ & & Carbon black & & 3.15 \\
\hline \multirow{2}{*}{ Oil } & $0.85 \mathrm{~kg}$ & & Diesel & & 514.85 \\
\hline & & & Natural gas & & 254.855 \\
\hline \multicolumn{6}{|c|}{ Considered output (all in kg) } \\
\hline & & Electricity & \multicolumn{3}{|c|}{ Diesel } \\
\hline \multicolumn{2}{|l|}{ Coal consumption } & $3.15 \mathrm{E}+01$ & \multicolumn{3}{|c|}{0} \\
\hline \multicolumn{2}{|l|}{ Oil consumption } & $1.80 \mathrm{E}-01$ & \multicolumn{3}{|c|}{$3.12 \mathrm{E}-02$} \\
\hline \multicolumn{2}{|l|}{ Natural gas consumption } & $7.74 \mathrm{E}-03$ & \multicolumn{3}{|c|}{$0.00 \mathrm{E}+00$} \\
\hline \multicolumn{2}{|l|}{$\mathrm{CO}_{2}$} & $6.66 \mathrm{E}+01$ & \multicolumn{3}{|c|}{$9.64 \mathrm{E}-02$} \\
\hline \multicolumn{2}{|l|}{$\mathrm{SO}_{2}$} & 4.01E-01 & \multicolumn{3}{|c|}{ 7.52E-05 } \\
\hline \multicolumn{2}{|l|}{$\mathrm{NO}_{x}$} & $1.66 \mathrm{E}-01$ & \multicolumn{3}{|c|}{$1.71 \mathrm{E}-03$} \\
\hline \multicolumn{2}{|l|}{$\mathrm{CO}$} & 3.04E-03 & \multicolumn{3}{|c|}{ 8.54E-04 } \\
\hline \multicolumn{2}{|l|}{$\mathrm{CH}_{4}$} & $1.51 \mathrm{E}-01$ & \multicolumn{3}{|c|}{$1.02 \mathrm{E}-05$} \\
\hline \multicolumn{2}{|l|}{ Particle matter } & $8.16 \mathrm{E}-03$ & \multicolumn{3}{|c|}{$2.24 \mathrm{E}-01$} \\
\hline
\end{tabular}

Table 4. Input-output data for catalytic pyrolysis (15 wt\% fly ash) of LLDPE $[41,44,47]$

\begin{tabular}{|c|c|c|c|c|c|}
\hline \multicolumn{6}{|c|}{1 ton of LLDPE sent to catalytic pyrolysis ( $15 \mathrm{wt} \%$ fly ash) } \\
\hline \multicolumn{3}{|l|}{ Considered input } & \multicolumn{3}{|c|}{ Valuable output (all in kg) } \\
\hline Electricity & $213.83 \mathrm{MJ}$ & & Diesel & & 402.83 \\
\hline Oil & $1.08 \mathrm{~kg}$ & & Natural gas & & 364.47 \\
\hline \multicolumn{6}{|c|}{ Considered output (all in kg) } \\
\hline & & Electricity & \multicolumn{3}{|c|}{ Diesel } \\
\hline Coal consumption & & $3.14 \mathrm{E}+01$ & \multicolumn{3}{|c|}{0} \\
\hline Oil consumption & & $1.80 \mathrm{E}-01$ & \multicolumn{3}{|c|}{$3.96 \mathrm{E}-02$} \\
\hline Natural gas consumption & & 7.72E-03 & \multicolumn{3}{|c|}{$0.00 \mathrm{E}+00$} \\
\hline $\mathrm{CO}_{2}$ & & $6.65 \mathrm{E}+01$ & \multicolumn{3}{|c|}{$1.22 \mathrm{E}-01$} \\
\hline $\mathrm{SO}_{2}$ & & 4.00E-01 & \multicolumn{3}{|c|}{$9.54 \mathrm{E}-05$} \\
\hline $\mathrm{NO}_{x}$ & & $1.66 \mathrm{E}-01$ & \multicolumn{3}{|c|}{ 2.17E-03 } \\
\hline $\mathrm{CO}$ & & $3.04 \mathrm{E}-03$ & \multicolumn{3}{|c|}{$1.08 \mathrm{E}-03$} \\
\hline $\mathrm{CH}_{4}$ & & $1.51 \mathrm{E}-01$ & \multicolumn{3}{|c|}{$1.30 \mathrm{E}-05$} \\
\hline Particle matter & & $8.14 \mathrm{E}-03$ & \multicolumn{3}{|c|}{$2.85 \mathrm{E}-01$} \\
\hline Solid waste & & $6.97 \mathrm{E}+01$ & \multicolumn{3}{|c|}{0} \\
\hline
\end{tabular}

Table 5. Input-output data for catalytic pyrolysis (15 wt\% bottom ash) of LLDPE $[41,44,47]$

\begin{tabular}{|c|c|c|c|c|c|}
\hline \multicolumn{6}{|c|}{1 ton of LLDPE sent to catalytic pyrolysis ( $15 \mathrm{wt} \%$ bottom ash) } \\
\hline \multicolumn{3}{|l|}{ Considered input } & \multicolumn{3}{|c|}{ Valuable output (all in kg) } \\
\hline Electricity & $213.41 \mathrm{MJ}$ & & Diesel & & 380.08 \\
\hline Oil & $1.08 \mathrm{~kg}$ & & Natural gas & & 394.63 \\
\hline \multicolumn{6}{|c|}{ Considered output (all in kg) } \\
\hline & & Electricity & \multicolumn{3}{|c|}{ Diesel } \\
\hline Coal consumption & & $3.14 \mathrm{E}+01$ & \multicolumn{3}{|c|}{0} \\
\hline Oil consumption & & $1.80 \mathrm{E}-01$ & \multicolumn{3}{|c|}{ 3.94E-02 } \\
\hline Natural gas consumption & & 7.70E-03 & \multicolumn{3}{|c|}{$0.00 \mathrm{E}+00$} \\
\hline $\mathrm{CO}_{2}$ & & $6.64 \mathrm{E}+01$ & \multicolumn{3}{|c|}{$1.22 \mathrm{E}-01$} \\
\hline $\mathrm{SO}_{2}$ & & 3.99E-01 & \multicolumn{3}{|c|}{ 9.49E-05 } \\
\hline $\mathrm{NO}_{x}$ & & $1.65 \mathrm{E}-01$ & \multicolumn{3}{|c|}{$2.16 \mathrm{E}-03$} \\
\hline $\mathrm{CO}$ & & 3.03E-03 & \multicolumn{3}{|c|}{$1.08 \mathrm{E}-03$} \\
\hline $\mathrm{CH}_{4}$ & & $1.51 \mathrm{E}-01$ & \multicolumn{3}{|c|}{$1.29 \mathrm{E}-05$} \\
\hline Particle matter & & 8.12E-03 & \multicolumn{3}{|c|}{$2.83 \mathrm{E}-01$} \\
\hline Solid waste & & $6.04 \mathrm{E}+01$ & \multicolumn{3}{|c|}{0} \\
\hline
\end{tabular}


Table 6. Emissions per MJ electricity and per/t. $\mathrm{km}$ transportation consumption [44]

\begin{tabular}{|c|c|c|}
\hline Public system & $\begin{array}{c}\text { Electricity } \\
(\mathrm{kg} / \mathrm{MJ})\end{array}$ & $\begin{array}{c}\text { Transportation } \\
(\mathrm{kg} / \mathrm{t} \cdot \mathrm{km})\end{array}$ \\
\hline Coal consumption (kg) & $1.47 \mathrm{E}-01$ & 0 \\
\hline Oil consumption (kg) & 8.42E-04 & $3.65 \mathrm{E}-02$ \\
\hline Natural gas consumption $(\mathrm{kg})$ & 3.61E-05 & 0 \\
\hline $\mathrm{CO}_{2}(\mathrm{~kg})$ & $3.11 \mathrm{E}-01$ & $1.13 \mathrm{E}-01$ \\
\hline $\mathrm{SO}_{2}(\mathrm{~kg})$ & $1.87 \mathrm{E}-03$ & 8.80E-05 \\
\hline $\mathrm{NO}_{x}(\mathrm{~kg})$ & 7.75E-04 & 2.00E-03 \\
\hline $\mathrm{CO}(\mathrm{kg})$ & $1.42 \mathrm{E}-05$ & $1.00 \mathrm{E}-03$ \\
\hline $\mathrm{CH}_{4}(\mathrm{~kg})$ & $7.06 \mathrm{E}-04$ & $1.20 \mathrm{E}-05$ \\
\hline Particle matter (kg) & 3.81E-05 & 2.63E-01 \\
\hline
\end{tabular}

sis compiled in Tables 3-5 were sourced from the Chinese reference life cycle database [44] and reports describing related waste plastic recovery technologies [41,47]. Table 3 list the input-output data for non-catalytic pyrolysis of LLDPE, and the input-output data for LLDPE pyrolysis blending with fly ash and bottom ash are reported in Tables 4 and 5, respectively. Table 6 shows the air emissions per megajoule of electricity generated in China and those per ton-kilometer of diesel consumed in the transportation process [44].

\section{RESULTS AND DISCUSSIONS}

\section{Characterization of Raw Materials}

Table 7 lists the results of the proximate analysis of the two types of coal ash and the LLDPE. That of LLDPE included a volatile content of $99.45 \%$ and $0.55 \%$ moisture. The moisture content was higher in the fly ash than that in the bottom ash, at $0.30 \%$ and $0.11 \%$, respectively. The bottom ash presented higher volatile and fixed carbon content of $1.07 \%$ and $0.11 \%$, respectively, than that of fly ash, at $0.94 \%$ and $0.05 \%$, respectively. The ash content of two types of ash was same, at $98.71 \%$. LLDPE is mainly comprised of $\mathrm{C}$ and $\mathrm{H}$, which in total makes up to 97.74 wt\%, as shown in Table 7.

Table 8 shows the mineral compositions of the two types of coal ash. Both contained high levels of $\mathrm{SiO}_{2}, \mathrm{Al}_{2} \mathrm{O}_{3}, \mathrm{CaO}$, and $\mathrm{Fe}_{2} \mathrm{O}_{3}$. The $\mathrm{Na}_{2} \mathrm{O}$ and $\mathrm{MgO}$ content of the coal ash was almost negligible, at less than $0.4 \%$. The $\mathrm{SiO}_{2}, \mathrm{Al}_{2} \mathrm{O}_{3}$, and $\mathrm{CaO}$ content was higher compared with the other mineral components. The $\mathrm{CaO}$ content was greater in the coal bottom ash than in the coal fly ash, at

Table 7. Proximate analysis of LLDPE, fly ash, and bottom ash, as well as ultimate analysis of LLDPE

\begin{tabular}{lrcc}
\hline \hline Sample & LLDPE & Fly ash & Bottom ash \\
\hline Moisture & 0.55 & 0.30 & 0.11 \\
Volatile & 99.45 & 0.94 & 1.07 \\
Fixed carbon & 0.00 & 0.05 & 0.11 \\
Ash & 0.00 & 98.71 & 98.71 \\
Ultimate analysis of LLDPE: C (84.15 wt\%), H (13.59 wt\%), O \\
(2.18 wt\%), N (0.05 wt\%), S (0.03 wt\%) \\
\hline
\end{tabular}

Table 8. Mineral composition of fly ash and bottom ash using XRF

\begin{tabular}{lcc}
\hline \hline Mineral composition (\%) & Fly ash & Bottom ash \\
\hline $\mathrm{Na}_{2} \mathrm{O}$ & 0.2 & 0.18 \\
$\mathrm{MgO}$ & 0.38 & 0.39 \\
$\mathrm{Al}_{2} \mathrm{O}_{3}$ & 23.11 & 23.2 \\
$\mathrm{SiO}_{2}$ & 43.17 & 38.15 \\
$\mathrm{~K}_{2} \mathrm{O}$ & 1.91 & 1.28 \\
$\mathrm{CaO}$ & 18.42 & 23.55 \\
$\mathrm{Fe}_{2} \mathrm{O}_{3}$ & 12.81 & 13.25 \\
$\mathrm{R}_{\mathrm{B} / \mathrm{A}}$ & 0.51 & 0.63 \\
$\mathrm{R}_{\mathrm{Fe} / \mathrm{Ca}}$ & 1.39 & 1.13 \\
\hline
\end{tabular}

$22.98 \%$ and $18.06 \%$, respectively. The metal oxides in the coal ash could be sub-divided into basic metal oxide and acidic metal oxides [34]. Basic metal oxides could improve the quality of biooil, while acidic metal oxides inhibit coke formation [48]. As shown in Table 8 , the $\mathrm{R}_{B / A}$ of bottom ash (0.63) is higher than that of fly ash (0.51), thus implying higher catalytic activity. Moreover, fly ash with higher $\mathrm{R}_{\mathrm{Fe} / \mathrm{Ca}}$ is expected to enhance the gas yield, which has also been demonstrated in Table 1 and verified with previous study [35]. 1-1. TG and DTG Analysis of LLDPE Non-catalytic Pyrolysis and Pyrolysis

The thermogravimetric (TG) curves and derivative thermogravimetric (DTG) curves of the LLDPE pyrolysis with the different coal ash types are shown in Fig. 2(a)-(d). Table 9 lists the initial temperatures $\left(\mathrm{T}_{i}\right)$, maximum decomposition temperatures $\left(\mathrm{T}_{\text {max }}\right)$, and final temperatures $\left(\mathrm{T}_{f}\right)$ for the LLDPE pyrolysis. The pyrolysis interval of LLDPE and LLDPE blended with coal ash was 425$508^{\circ} \mathrm{C}$, and the $\mathrm{T}_{\max }$ values of the DTG were $478-481^{\circ} \mathrm{C}$. The thermogravimetric (TG) curves and derivative thermogravimetric (DTG) curves of the LLDPE pyrolysis with the different coal ash types are shown in Fig. 2(a)-(d). Table 9 lists the initial temperature $\left(T_{i}\right)$, maximum decomposition temperature $\left(\mathrm{T}_{\max }\right)$, and final temperature $\left(\mathrm{T}_{f}\right)$ for the LLDPE pyrolysis. The pyrolysis interval of LLDPE and LLDPE blended with coal ash was $425-508^{\circ} \mathrm{C}$, and the $\mathrm{T}_{\max }$ values of the DTG were $478-481^{\circ} \mathrm{C}$. The decomposition rate decreased as the ash ratio increased, as shown in Figs. 2(c) and (d). The basic catalysts, such as $\mathrm{CaO}$, could suppress the yield of volatiles at high temperature [49]. The decrease in LLDPE decomposition rate was more significant with the addition of bottom ash compared with that of the fly ash, which could be attributed to the higher alkaline content in bottom ash, as evident from the $\mathrm{R}_{B / A}$.

Additionally, the $\mathrm{T}_{\max }$ values for the decomposition temperature

Table 9. Maximum decomposition temperatures on the DTG curves obtained from the non-catalytic and catalytic pyrolysis of LLDPE over coal fly ash and coal bottom ash

\begin{tabular}{lccc}
\hline \hline Items & $\mathrm{T}_{i}$ & $\mathrm{~T}_{\max }$ & $\mathrm{T}_{f}$ \\
\hline Non-catalytic pyrolysis & 425 & 481 & 508 \\
Catalytic pyrolysis (5 wt\% fly ash) & 425 & 480 & 508 \\
Catalytic pyrolysis (15 wt\% fly ash) & 425 & 478 & 508 \\
Catalytic pyrolysis (5 wt\% bottom ash) & 425 & 481 & 508 \\
Catalytic pyrolysis (15 wt\% bottom ash) & 425 & 480 & 508 \\
\hline
\end{tabular}


(a)

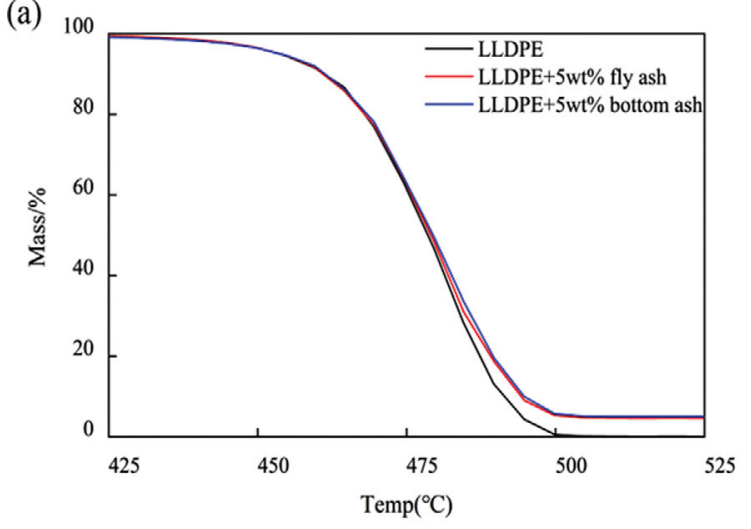

(c)

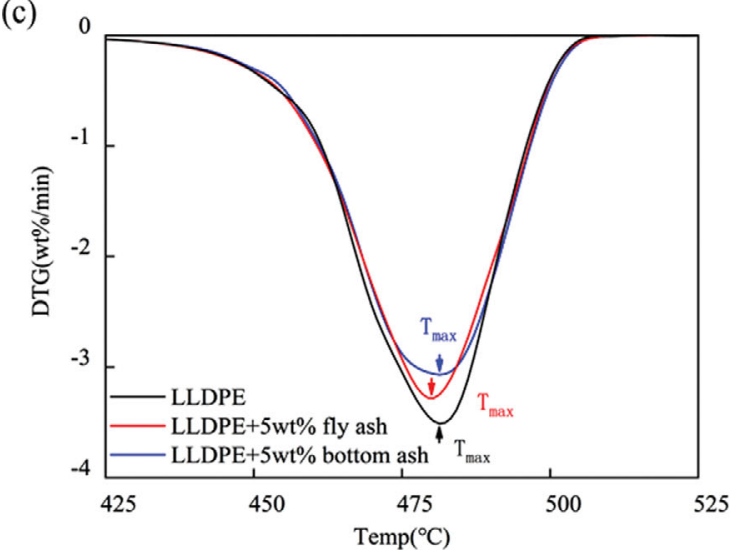

(b)

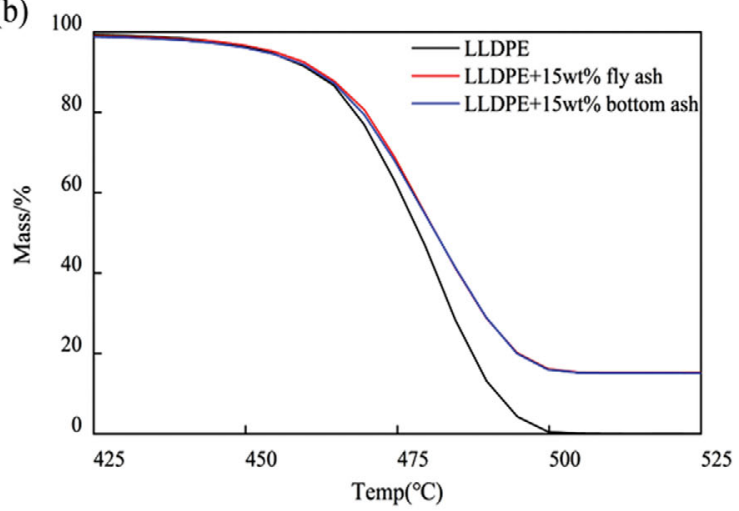

(d)

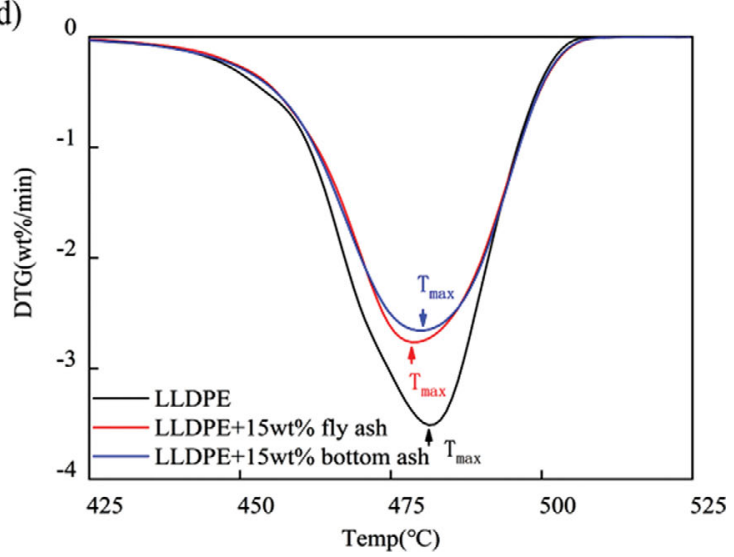

Fig. 2. TG and DTG curves of LLDPE using coal ash as catalyst. (a) TG curve of $5 \mathrm{wt} \% \mathrm{fly}$ ash/bottom ash as catalyst; (b) TG curve of $15 \mathrm{wt} \%$ fly ash/bottom ash as catalyst; (c) DTG curve of $5 \mathrm{wt} \%$ fly ash/bottom ash as catalyst; (d) DTG curve of $5 \mathrm{wt} \%$ fly ash/bottom ash as catalyst.

Table 10. Kinetic Parameters of the LLDPE thermal and catalytic pyrolysis

\begin{tabular}{|c|c|c|c|c|c|}
\hline Items & $\begin{array}{l}\text { Heating rate } \\
\left({ }^{\circ} \mathrm{C} \cdot \mathrm{min}^{-1}\right)\end{array}$ & $\begin{array}{l}\text { Temperature interval } \\
\left(\left({ }^{\circ} \mathrm{C}\right)\right.\end{array}$ & $\begin{array}{c}\text { Activation energy } \\
\left(\mathrm{kJ} \cdot \mathrm{mol}^{-1}\right)\end{array}$ & $\begin{array}{c}\mathrm{A} \\
\left(\times 10^{31} \mathrm{~min}^{-1}\right)\end{array}$ & $\mathrm{R}^{2}$ \\
\hline Non-catalytic pyrolysis & 10 & $415-508$ & 458.73 & 4.87 & 0.998 \\
\hline Catalytic pyrolysis (5 wt\% fly ash) & 10 & $415-508$ & 456.87 & 3.65 & 0.997 \\
\hline Catalytic pyrolysis (15 wt\% fly ash) & 10 & 415-508 & 444.49 & 0.45 & 0.999 \\
\hline Catalytic pyrolysis ( $5 \mathrm{wt} \%$ bottom ash) & 10 & 415-508 & 441.95 & 0.31 & 0.999 \\
\hline Catalytic pyrolysis ( $15 \mathrm{wt} \%$ bottom ash) & 10 & $415-508$ & 437.78 & 0.16 & 0.999 \\
\hline
\end{tabular}

interval on the DTG curve of LLDPE was slightly decreased with coal ash, from $481^{\circ} \mathrm{C}$ for non-catalytic TG analysis to $478^{\circ} \mathrm{C}$ with $15 \mathrm{wt} \%$ fly ash, $480^{\circ} \mathrm{C}$ with $5 \mathrm{wt} \%$ fly ash, $480^{\circ} \mathrm{C}$ with $15 \mathrm{wt} \%$ bottom ash, and $481^{\circ} \mathrm{C}$ with $5 \mathrm{wt} \%$ bottom ash. This suggests that the coal ash accelerated the LLDPE decomposition. The addition of $\mathrm{CaO}$ could lead to the decrease in maximum decomposition temperature during pyrolysis [50], thus indicating that $\mathrm{CaO}$ in coal ash could result in accelerated decomposition. However, as shown in Fig. 2, the $\mathrm{T}_{\max }$ for $15 \mathrm{wt} \%$ fly ash was $2{ }^{\circ} \mathrm{C}$ lower than that of LLDPE pyrolysis with $15 \mathrm{wt} \%$ bottom ash. This is possibly due to the coke formation and subsequent altering of the pore structure of the ash samples and weakening the catalytic activity [51,52]. 1-2. Model-fitting Kinetics Calculation

Table 10 lists the values of activation energy, heating rate, tem- perature interval, pre-exponential factor, and correlation coefficient $\left(\mathrm{R}^{2}\right)$ obtained from the Coats-Redfern method for LLDPE. The values of activation energy were distributed as $458.73 \mathrm{~kJ} \cdot \mathrm{mol}^{-1}$, $456.87 \mathrm{~kJ} \cdot \mathrm{mol}^{-1}, 444.49 \mathrm{~kJ} \cdot \mathrm{mol}^{-1}, 441.95 \mathrm{~kJ} \cdot \mathrm{mol}^{-1}$ and $437.78 \mathrm{~kJ} \cdot \mathrm{mol}^{-1}$ for LLDPE, LLDPE blended with $5 \mathrm{wt} \%$ fly ash, LLDPE blended with $15 \mathrm{wt} \%$ fly ash, LLDPE blended with $5 \mathrm{wt} \%$ bottom ash, and LLDPE blended with $15 \mathrm{wt} \%$ bottom ash, respectively. These results can be attributed to the different mineral-organic interactions in the various pyrolysis cases [27]. The activation energy of LLDPE with $15 \mathrm{wt} \%$ bottom ash had the most significant reduction, at $20.95 \mathrm{~kJ} \cdot \mathrm{mol}^{-1}$, compared with the other cases. The value of the pre-exponential factor varied greatly, which is reflected in the orders of magnitude. The correlation coefficients obtained from the reaction mechanism functions were above 0.99 , which proves 
that calculating the kinetic parameters using the Coats-Redfern method is reliable. These results are similar to those reported by $\mathrm{Xu}$ [38].

Table 10 indicates that the activation energy was lower with the addition of coal ash, and the catalytic effect of the bottom ash was better than that of the fly ash for at the same blending ratio. This can be explained by the catalytic effect of AAEM oxides in coal ash, particularly the high content of $\mathrm{CaO}$. The same result was reported in previous pyrolysis studies. Day et al. [53] investigated polypropylene pyrolysis in the presence of iron oxide. The results showed that in the presence of $5 \% \mathrm{Fe}_{2} \mathrm{O}_{3}$, the degradation process accelerated by $100 \%$ according to the rate constant at $400{ }^{\circ} \mathrm{C}$ and that the activation energy differed significantly, at about $22 \%$ lower. Ma et al. [54] showed that sludge pyrolysis process with $10 \%$ of $\mathrm{CaO}$ led to a decline in activation energy. However, details of the catalytic mechanisms of AAEM oxides require further investigation.

1-3. Pyrolysis Liquid Yields

Fig. 3 shows the main components of the oil yielded from the pyrolysis of LLDPE with and without the addition of fly ash/bottom ash at two blending ratios. Alkane and alkenes are the predominant compounds for all tested samples. It is consistent with the typical depropagation mechanism of polymers where LLDPE decomposes into short-chain alkanes and alkenes at elevated temperature [52]. Compared with the non-catalytic pyrolysis, coal ash increased the yield of alicyclic hydrocarbons and aromatics. This is due to the carbanion mechanism where the formation of unstable carbanion facilitates low molecular weight production [11], as discussed in Introduction Section. The basic sites in coal ash can abstract a proton from a long-chain hydrocarbon to form a carbanion. Moreover, coal ash can promote the $\beta$-scission of carbanion, producing short-chain alkenes, which could act as feedstocks to aromatics production, known as the Diels-Alder reaction [12]. The overall aromatic yield of catalytic pyrolysis with $5 \mathrm{wt} \%$ bottom ash was higher than that with $5 \mathrm{wt} \%$ fly ash owing to its higher $\mathrm{R}_{B / A}$ value. However, when the blending ratio of bottom ash was further increased to $15 \mathrm{wt} \%$, the aromatic content decreased drastically, while the content of alicyclic hydrocarbon increased from $5.97 \%$ to $32.09 \%$. This may be because $\mathrm{Fe}_{2} \mathrm{O}_{3}$ would enhance the hydrogenation activity of coal ash. Thus, it would also hinder the dehydrogenation process in Diels-Alder reaction, thus decreasing the aromatic yield.

\section{LCA Discussion}

LCA of the global and European economic systems for 2000 was selected owing to its comprehensive characterization [55]. The following factors were considered: acidification (in $\mathrm{kg} \mathrm{SO}_{2}$-eq), climate change ( $\mathrm{kg} \mathrm{CO}_{2}$-eq), particle matter $\left(\mathrm{kg} \mathrm{PM}_{10} / \mathrm{m}^{3} \cdot \mathrm{a}\right)$, fossil energy resource depletion (kg.oil-eq), urban land occupation ( $\left.\mathrm{m}^{2} / \mathrm{a}\right)$.

In addition, the total net energy output was considered, as calculated from the total potential worth of energy output minus the amount consumed for each of the three plastic waste management options [41].

2-1. Environmental Impact Results

The environmental impact results for acidification, climate change, particle matter, fossil energy resource depletion, and urban land occupation are presented in Figs. 4(a)-(e). In most cases, scenario 3 played a significant role in mitigating the potential environmental effects. $\mathrm{CO}_{2}$ and $\mathrm{SO}_{2}$ emissions as well as fossil fuel consumption were derived mostly from the electricity generation process because a large amount of electricity is consumed in LLDPE pyrolysis. The highest emission of $\mathrm{CO}_{2}$ was $70.53 \mathrm{~kg} \mathrm{CO}$-eq (scenario 1), and the lowest was $70.26 \mathrm{~kg} \mathrm{CO}_{2}$-eq (scenario 3), as shown in Fig. 4(b). This occurred because catalytic pyrolysis reduces the energy consumption when high temperatures are maintained in the pyrolysis process.

As shown in Fig. 4(a), the acidification effects from scenario 1 were $0.495 \mathrm{~kg} \mathrm{SO}_{2}$-eq to $0.493 \mathrm{~kg} \mathrm{SO}_{2}$-eq (scenario 3); Fig. 4(d) shows fossil fuel consumption of 13.36 to $13.31 \mathrm{~kg}$.oil-eq for scenario 1 to the catalytic pyrolysis (scenario 3 ). In these three environmental impact categories, the height of the peak followed the order of scenario $1>$ scenario $2>$ scenario 3 . This result is attributed to the addition of coal ash for reducing the electrical power consumption.

Unlike that for climate change, the potential particle matter effects, shown in Fig. 4(c), increased slightly from scenarios 1 to 2; then, the value was almost identical from scenario 2 to 3 . The potential particle matter was derived mostly from transportation

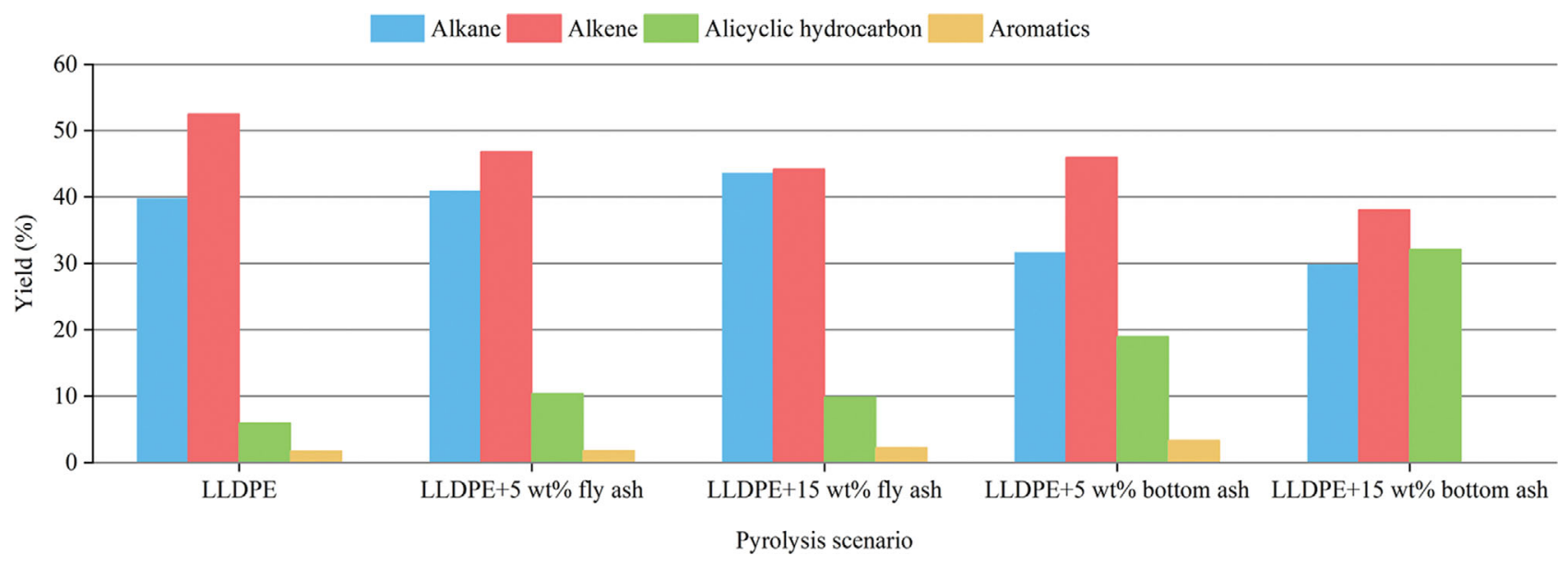

Fig. 3. Relative fraction (\%) of major components in oil generated from LLDPE pyrolysis. 
(a)

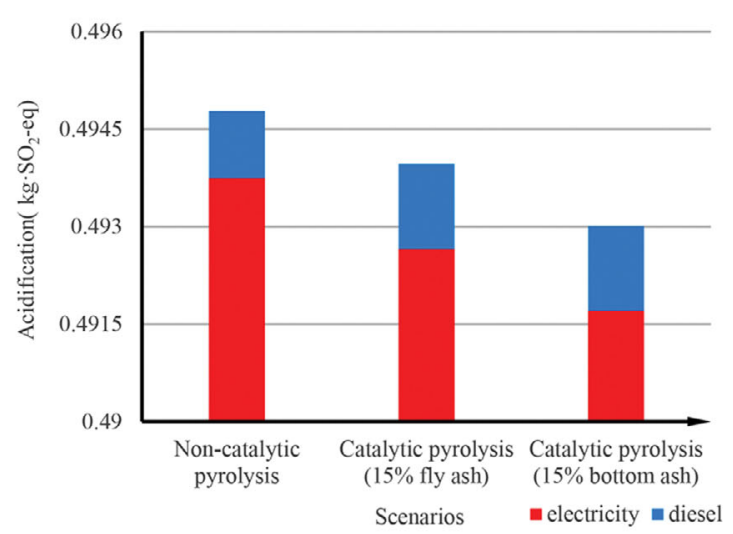

(c)

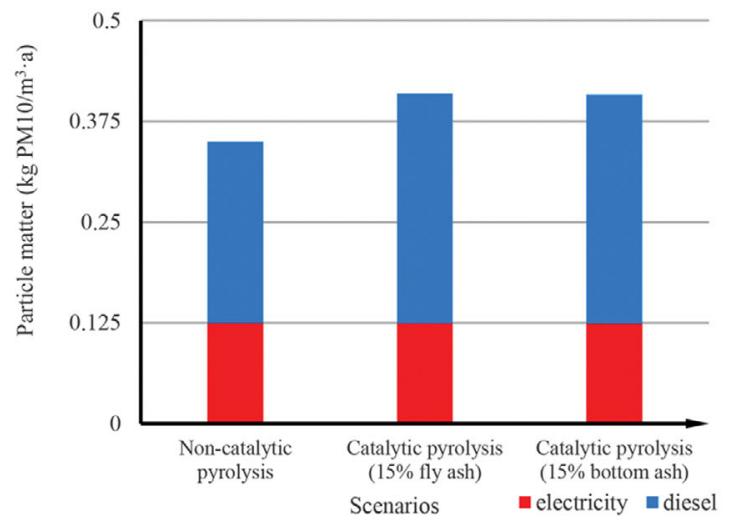

(e)

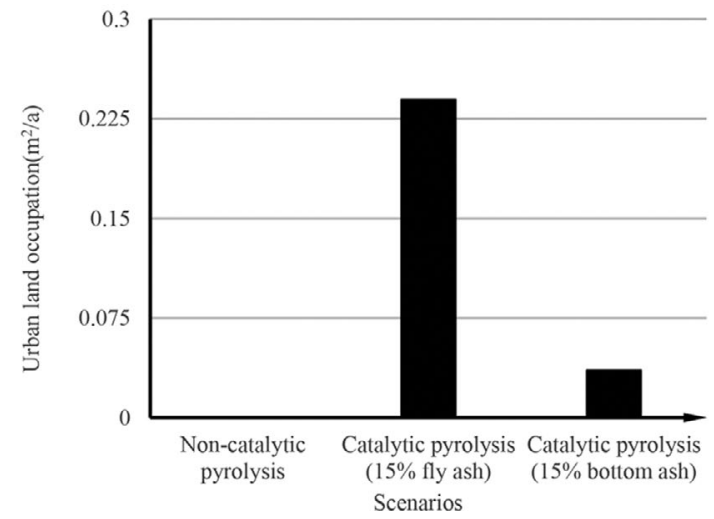

(b)

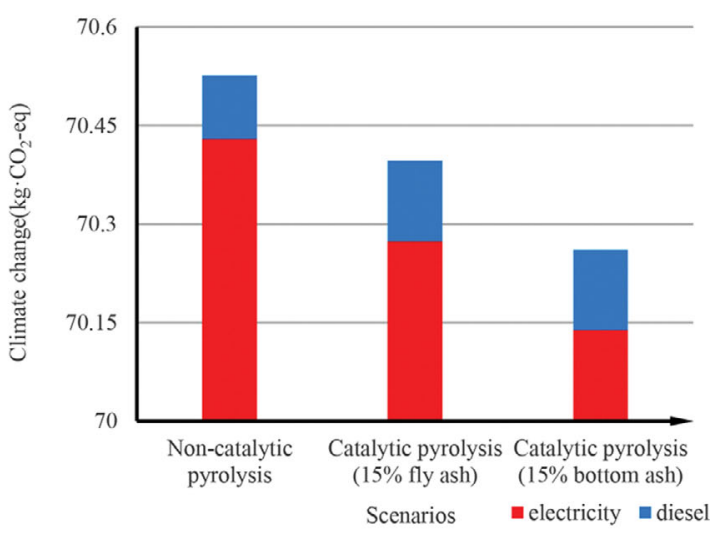

(d)

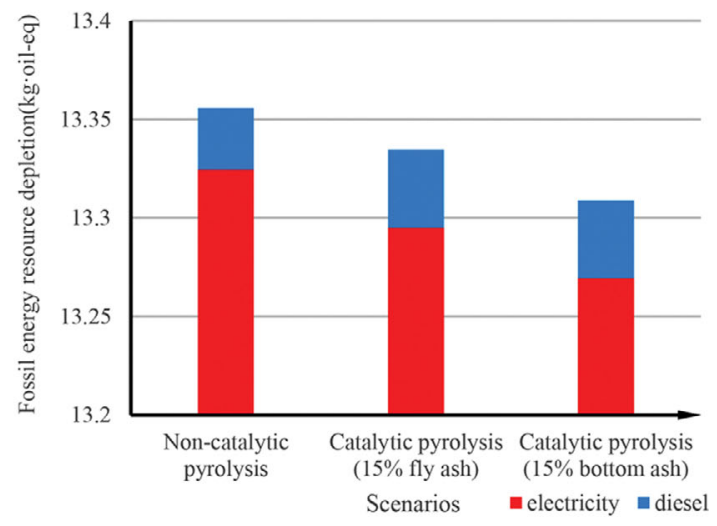

(f)

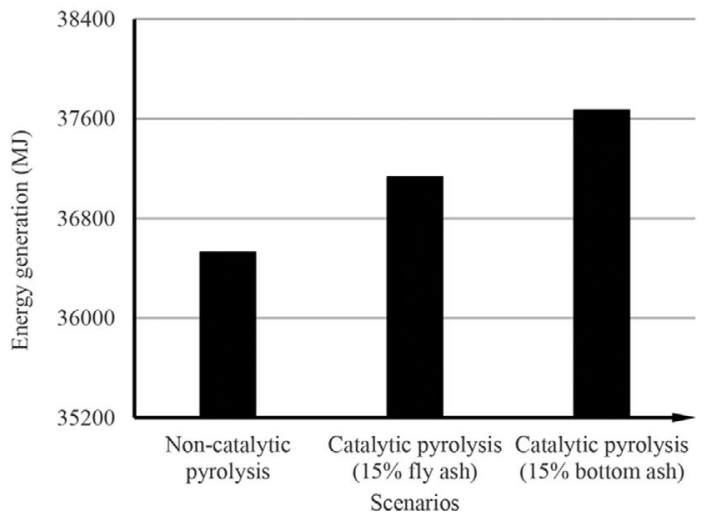

Fig. 4. Environmental impacts of using coal ash as catalyst. (a) Acidification; (b) Climate change; (c) particle matter; (d) Fossil energy resource depletion; (e) Urban land occupation; (f) Energy generation.

emissions $\left(\mathrm{SO}_{x}, \mathrm{PM}_{x}\right.$, and $\left.\mathrm{NO}_{x}\right)$. Fig. 4(e) presents the levels of potential urban land occupation. The highest peaks, shown in scenario 2, are attributed to waste from LLDPE pyrolysis. In scenario 1 , the solid product was counted as carbon black with commercial use; in scenario 3, approximately $0.036 \mathrm{~m}^{2}$ of land was occupied annually by the distributed solid waste, which was lower than that in scenario 2, at $0.239 \mathrm{~m}^{2}$. The addition of coal ash changed the pyrolysis product composition, which led to the variation in potential urban land occupation.

Resource recovery is one of the highest incentives for waste plastic recycling management because the synoil and syngas exhibit high CCI and HHV values, respectively. These products are alternatives to fossil fuels. Fig. 4(f) shows the potential net energy out- put from the LLDPE pyrolysis process. Scenario 3 had the highest energy yield, at 37,668.53 MJ, compared with scenarios 1 and 2, at $36,527.14 \mathrm{MJ}$ and $37,130.96 \mathrm{MJ}$, respectively, because the addition of coal ash increased the gas-oil ratio of the product. Moreover, the calorific value per kilogram of the syngas was higher than that of the synoil.

\section{2-2. Normalization and Weighting Scores}

The comparison of separate impact indicators was inconclusive regarding the overall effect of coal ash on LLDPE pyrolysis. Thus, normalization and weighting process are essential for the LCA report. The calculated effects were divided according to selected reference values to explain the individual impact indicators and to generate one score for comparing several technological options 
using weighting factors [56].

A similar normalization scenario was needed to compare the three LLDPE management scenarios. Thus, Scenario 2 was used as the normalized reference against scenarios 1 and 3 instead of worldwide normalized reference.

After the normalization process, weighting factors were assigned to each impact category to show their value and to integrate the normalized results into one score. Among all environmental categories listed, fossil fuel consumption and particle matter were considered to be the most important items [57]. Because synoil and syngas from LLDPE pyrolysis are considered as valuable outputs rather than environmental burdens, the energy generation weighted score should be negative. The normalized and weighted scores are compiled in Table 11.

According to the normalization and weighting results shown in Fig. 5, scenario 3 was the optimal scenario based on the lowest scores at a total of 2.83. A reduction of $0.047 \mathrm{~kg}$ of potential fossil energy resource depletion can be achieved via the distribution of 1 ton of LLDPE for catalytic pyrolysis ( $15 \mathrm{wt} \%$ bottom ash) compared with that for non-catalytic pyrolysis, at a total value of 3.39 . Additionally, a combined total of $37,668.53 \mathrm{MJ}$ in potential net worth of energy can be produced. However, this resulted in the

Table 11. Normalized and weighting factors

\begin{tabular}{llcc}
\hline \hline Item & Unit & Normalized scores & Weighting factors \\
\hline Acidification & $\mathrm{kg} \mathrm{SO}_{2}$-eq & 0.4940 & 1.18 \\
Climate change & $\mathrm{kg} \mathrm{CO}_{2}$-eq & 70.40 & 1.16 \\
Particle matter & $\mathrm{kg} \mathrm{PM}_{10} / \mathrm{m}^{3} \cdot \mathrm{a}$ & 0.4097 & 1.21 \\
Fossil energy resource depletion & $\mathrm{kg} \mathrm{oil-eq}$ & 13.33 & 1 \\
Urban land occupation & $\mathrm{m} / \mathrm{a}$ & 0.2394 & 1.05 \\
Energy generation & $\mathrm{MJ}$ & $37,130.96$ & -1 \\
\hline
\end{tabular}

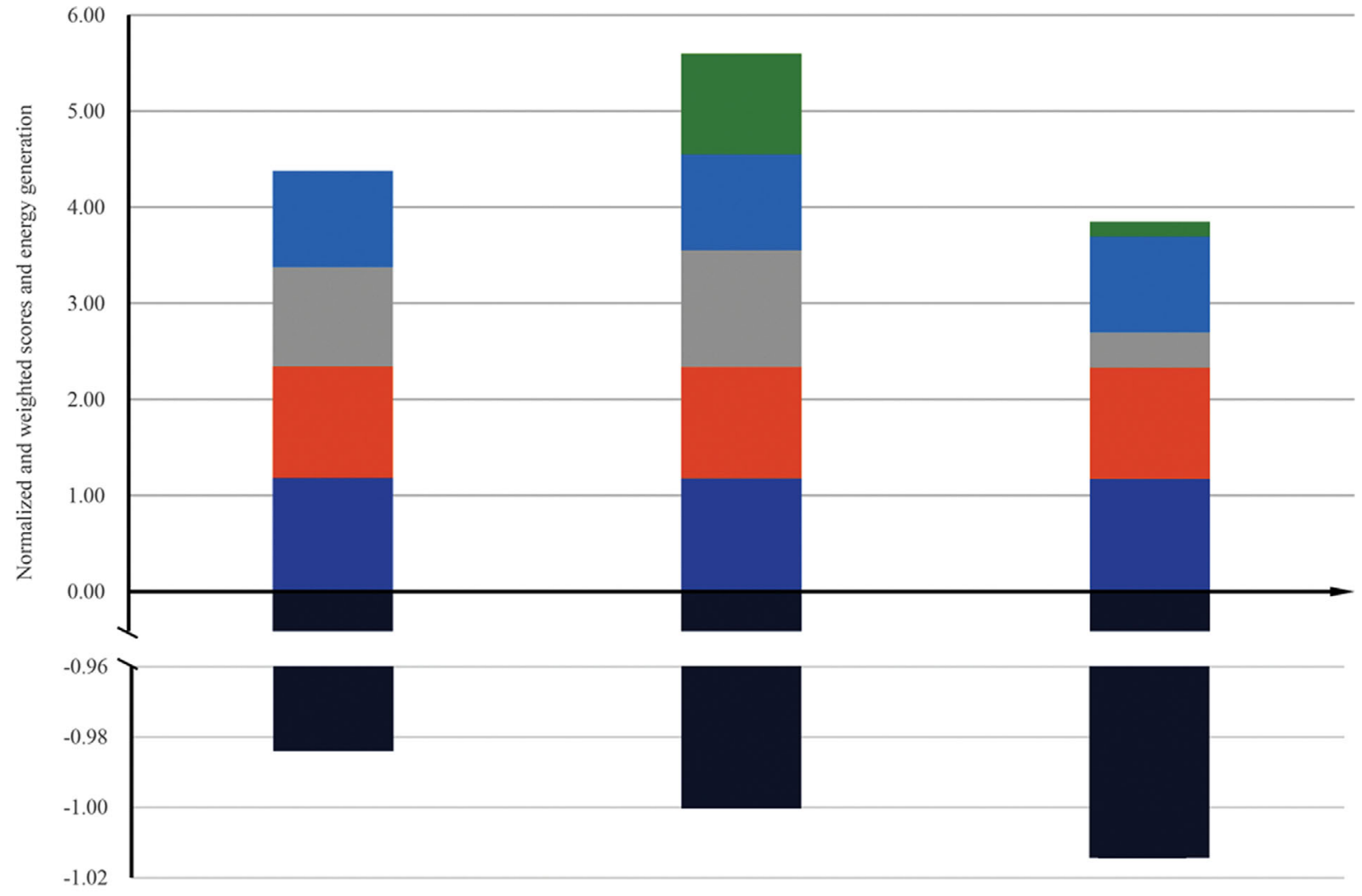

Non-catalytic pyrolysis

Acidification
- Fossil energy resource depletion
Catalytic pyrolysis ( $15 \%$ fly ash)

Catalytic pyrolysis ( $15 \%$ bottom ash)

Scenarios

- Climate change

- Urban land occupation
- Respiratory effects

- Energy generation

Fig. 5. Total normalized and weighted scores combine energy generation. 
release of $0.059 \mathrm{~kg} \mathrm{PM} / \mathrm{Pm}^{3} \cdot \mathrm{a}$ more than that released in the noncatalytic pyrolysis.

The worst LLDPE management was scenario 2, with a total value of 4.6. In this case, a net worth of $37,130.96 \mathrm{MJ}$ can be generated; however, $13.33 \mathrm{~kg}$ of potential fossil energy resource depletion is possible and $0.410 \mathrm{~kg}$ of particle matter can be released annually.

It should be emphasized that the weighting factors listed in Table 11 are presented according to the distance-to-target weighting method outlined in Europe 2020 [57]. The results can differ with the change of weighting factors [58]; therefore, the final scores shown in Fig. 4 can be influenced by changing the weighting factors [41].

\section{CONCLUSIONS}

Recovering valuable fuels from plastic waste via catalytic pyrolysis has been studied. Catalytic pyrolysis at high temperatures can produce large amounts of high-calorific hydrocarbon fuels with high content of carbon and hydrogen. However, the large expense of the catalyst limit the development of catalytic pyrolysis in industrial applications. In addition, the catalysts used in waste plastic catalytic pyrolysis cannot be reused many times because the coke generated at high temperatures can block the active sites of the catalyst.

This work presents a new perspective on the study of catalytic effects in industrial solid waste. Through kinetics study, we investigated the catalytic effect of coal ash in LLDPE pyrolysis. In addition, the LCA investigated the environmental impacts of three LLDPE management solutions considering one ton of LLDPE.

The results demonstrated that coal ash can reduce the activation energy in the pyrolysis process. The catalytic effect of bottom ash appeared to perform better than that of fly ash, possibly because of the higher $\mathrm{CaO}$ content in the bottom ash. Besides, the activation energy decreased with the increasing ash blending ratio. More specifically, $15 \mathrm{wt} \%$ bottom ash had the most significant influence on the activation energy, with a reduction of $20 \mathrm{~kJ} \cdot \mathrm{mol}^{-1}$. LCA report indicated catalytic pyrolysis using $15 \mathrm{wt} \%$ bottom ash can enhance the potential environmental benefits. Compared with non-catalytic pyrolysis, a reduction of $0.266 \mathrm{~kg} \mathrm{CO}_{2}$-eq, $0.002 \mathrm{~kg}$ $\mathrm{SO}_{2}$-eq, $0.047 \mathrm{~kg}$ oil-eq fossil energy resource depletion is achieved in catalytic pyrolysis using $15 \mathrm{wt} \%$ bottom ash on 1 ton of LLDPE to derive $37,668.53 \mathrm{MJ}$ potential net energy. Further, the final normalized and weighted scores of the LCA model were used to determine that Scenario 3 was the best waste plastic management solution, with the lowest total score of 2.8 .

\section{ACKNOWLEDGEMENTS}

The authors gratefully express gratitude to all parties who have contributed towards the success of this project, both financially and technically, especially the S\&T Innovation 2025 Major Special Programme (grant number 2018B10022) and the Ningbo Natural Science Foundation Programme (grant number 2018A610069) funded by the Ningbo Science and Technology Bureau, China, as well as the UNNC FoSE Faculty Inspiration Grant, China. The
Zhejiang Provincial Department of Science and Technology is also acknowledged for this research under its Provincial Key Laboratory Programme (2020E10018).

\section{NOMENCLATURE}

DTG : differential thermogravimetry

$\mathrm{HHV}$ : higher heating value

LCA : life cycle assessment

LCI : life cycle inventory

LDPE : low-density polyethylene

LLDPE : linear low-density polyethylene

$\mathrm{R}^{2} \quad$ : correlation coefficients

$\mathrm{R}_{B / A} \quad$ : alkali and alkali earth metals oxides to acidic oxides ratio

$\mathrm{T}_{f} \quad$ : final temperature

TG : thermogravimetry

TGA : thermogravimetric analyser

$\mathrm{T}_{i} \quad$ : initial temperature

$\mathrm{T}_{\max } \quad$ :maximum decomposition temperature

XRF :X-ray fluorescence

\section{REFERENCES}

1. M. W. Ryberg, A. Laurent and M. Hauschild, Mapping of global plastics value chain and plastics losses to the environment: with a particular focus on marine environment (2018).

2. R. V. Moharir and S. Kumar, J. Cleaner Production, 208, 65 (2019).

3. A. L. Patrício Silva, J. C. Prata, T. R. Walker, A. C. Duarte, W. Ouyang, D. Barcelò and T. Rocha-Santos, Chem. Eng. J., 405, 126683 (2021).

4. I. M. Maafa, Polymers, 13, 225 (2021).

5. J. J. Park, K. Park, J.-W. Park and D. C. Kim, Korean J. Chem. Eng., 19, 658 (2002).

6. A. López, I. de Marco, B. M. Caballero, M. F. Laresgoiti, A. Adrados and A. Aranzabal, Appl. Catal. B: Environ., 104, 211 (2011).

7. S. D. Stefanidis, S. A. Karakoulia, K. G. Kalogiannis, E. F. Iliopoulou, A. Delimitis, H. Yiannoulakis, T. Zampetakis, A. A. Lappas and K. S. Triantafyllidis, Appl. Catal. B: Environ., 196, 155 (2016).

8. Y. Fu, Y. Guo and K. Zhang, Energy Fuels, 30, 2428 (2016).

9. H. D. Franklin, W. A. Peters, F. Cariello and J. B. Howard, Ind. Eng. Chem. Process Des. Development, 20, 670 (1981).

10. Z. Huang, L. Qin, Z. Xu, W. Chen, F. Xing and J. Han, J. Energy Inst., 92, 835 (2019).

11. O. S. Woo, N. Ayala and L. J. Broadbelt, Catal. Today, 55, 161 (2000).

12. L. Fan, Y. Zhang, S. Liu, N. Zhou, P. Chen, Y. Liu, Y. Wang, P. Peng, Y. Cheng, M. Addy, H. Lei and R. Ruan, Energy Convers. Manage., 149, 432 (2017).

13. Z. Tang, S. Ma, J. Ding, Y. Wang, S. Zheng and G. Zhai, editors. Current status and prospect of fly ash utilization in China. Proc of World of Coal Ash Conference (WOCA) (2013).

14. K. C. Galbreath and C. J. Zygarlicke, Fuel Process. Technol., 65, 289 (2000).

15. H. Zhao, C. I. Ezeh, S. Yin, Z. Xie, C. H. Pang, C. Zheng, X. Gao and T. Wu, Appl. Catal. B: Environ., 263, 117829 (2020).

16. H. Zhao, G. Yang, C. H. Pang, H. Fan, P. Hall, S. Kingman and T. Wu, Energy Procedia, 75, 2421 (2015). 
17. S. Wang, F. Zhang, Q. Cai, L. Zhu and Z. Luo, Int. J. Hydrogen Energy, 40, 11406 (2015).

18. A. S. Al-Rahbi and P. T. Williams, J. Mater. Cycles Waste Manage., 21, 1224 (2019).

19. L. Gao and J. L. Goldfarb, J. Anal. Appl. Pyrol., 137, 96 (2019).

20. Y. W. Go and S. H. Yeom, Environ. Eng. Res., 24, 324 (2019).

21. M. Benedetti, L. Cafiero, D. De Angelis, A. Dell'Era, M. Pasquali, S. Stendardo, R. Tuffi and S. V. Ciprioti, Front. Environ. Sci. Eng., 11, 11 (2017).

22. Y. Rotliwala and P. Parikh, Energy Sources, Part A: Recovery, Utilization, and Environmental Effects, 34, 1055 (2012).

23. K. M. Rambau, N. M. Musyoka, N. Manyala, J. Ren, H. W. Langmi and M. K. Mathe, J. Environ. Sci. Health, Part A, 53, 1115 (2018).

24. E. Lester, C. Avila, C. H. Pang, O. Williams, J. Perkins, S. Gaddipatti, G. Tucker, J. M. Barraza, M. P. Trujillo-Uribe and T. Wu, Fuel, 232, 845 (2018).

25. C. H. Pang, E. Lester and T. Wu, Biomass \& Bioenergy, 119, 480 (2018).

26. P. J. Daley, O. Williams, C. H. Pang, T. Wu and E. Lester, Fuel, 251, 779 (2019).

27. L. Y. Tang, Y. X. Yan, Y. Meng, J. Y. Wang, P. Jiang, C. H. Pang and T. Wu, Innovative Solutions for Energy Transitions, 158, 1694 (2019).

28. G. Özsin and A. E. Pütün, Korean J. Chem. Eng., 35, 428 (2018).

29. K.-H. Lee and S. C. Oh, Korean J. Chem. Eng., 27, 139 (2010).

30. J. Chattopadhyay, C. Kim, R. Kim and D. Pak, Korean J. Chem. Eng., 25, 1047 (2009).

31. Y.X. Pang, Y. Yan, D. C. Foo, N. Sharmin, H. Zhao, E. Lester, T. Wu and C. H. Pang, The Study of Lignocellulosic Biomass Pyrolysis via Superpro Designer (2019).

32. K. Shi, J. Yan, J. A. Menéndez, X. Luo, G. Yang, Y. Chen, E. Lester and T. Wu, Front. Chem., 8, 3 (2020).

33. Y.X. Yan, Y. Meng, L. Y. Tang, E. T. Kostas, E. Lester, T. Wu and C. H. Pang, Energy Fuels, 33, 6463 (2019).

34. S. A. Lolja, H. Haxhi and D. Gjyli, Fuel, 79, 207 (2000).

35. X. Cheng, X. He, C. Chen and S. Yi, Energy Technol., 3, 1068 (2015).

36. Q. Hu, Y. Shen, J. W. Chew, T. Ge and C.-H. Wang, Chem. Eng. J., 379, 122346 (2020).

37. H. Iftikhar, M. Zeeshan, S. Iqbal, B. Muneer and M. Razzaq, Bioresour. Technol., 289, 121647 (2019).
38. F. Xu, B. Wang, D. Yang, J. Hao, Y. Qiao and Y. Tian, Energy Convers. Manage., 171, 1106 (2018).

39. S. Rana, J. K. Parikh and P. Mohanty, Korean J. Chem. Eng., 30, 626 (2013).

40. I. Dubdub and M. Al-Yaari, Polymers, 12, 891 (2020).

41. H. H. Khoo, Resources, Conservation and Recycling, 145, 67 (2019).

42. S. Wang, F. Liu, C. Chen and X. Xu, Korean J. Chem. Eng., 24, 495 (2007).

43. N. S. A. Rasid, S. S. A. Syed-Hassan, S. A. S. A. Kadir and M. Asadullah, Korean J. Chem. Eng., 301277 (2013).

44. X. Liu, H. Wang, J. Chen, Q. He, H. Zhang, R. Jiang, X. Chen and P. Hou, Acta Scientiae Circumstantiae, 30, 2136 (2010).

45. S. Gopinath, P. Devan and K. Pitchandi, RSC Adv., 10, 37266 (2020).

46. X.-F. Guo and G.-J. Kim, Plasma Chem. Plasma Process., 30, 75 (2010).

47. F. Perugini, M. L. Mastellone and U. Arena, Environ. Progress, 24, 137 (2005).

48. X. Chen, Q. Che, S. Li, Z. Liu, H. Yang, Y. Chen, X. Wang, J. Shao and H. Chen, Fuel Process. Technol., 196, 106180 (2019).

49. J. Wang, M. Zhang, M. Chen, F. Min, S. Zhang, Z. Ren and Y. Yan, Thermochim. Acta, 444, 110 (2006).

50. J. Shao, R. Yan, H. Chen, H. Yang and D. H. Lee, Fuel Process. Technol., 91, 1113 (2010).

51. A. Ochoa, J. Bilbao, A. G. Gayubo and P. Castaño, Renewable and Sustainable Energy Reviews, 119, 109600 (2020).

52. H. W. Ryu, H. W. Lee, J. Jae and Y.-K. Park, Energy, 179, 669 (2019).

53. M. Day, J. D. Cooney and M. MacKinnon, Polymer Degradation and Stability, 48, 341 (1995).

54. R. Ma, X. Huang, Y. Zhou, L. Fang, S. Sun, P. Zhang, X. Zhang and X. Zhao, Bioresour. Technol., 238, 616 (2017).

55. A. W. Sleeswijk, L. F. C. M. van Oers, J. B. Guinée, J. Struijs and M. A. J. Huijbregts, Sci. Total Environ., 390, 227 (2008).

56. H. H. Khoo, T.Z. Lim and R. B. H. Tan, Sci. Total Environ., 408, 1367 (2010).

57. V. Castellani, L. Benini, S. Sala and R. Pant, Int. J. Life Cycle Assessment, 21, 1159 (2016).

58. R. Heijungs, J. Guinée, R. Kleijn and V. Rovers, Int. J. Life Cycle Assessment, 12, 211 (2007). 